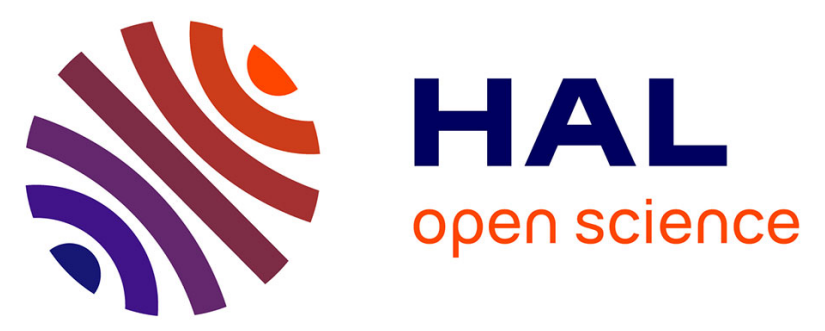

\title{
Budesonide/formoterol versus salmeterol/fluticasone in COPD: a systematic review and adjusted indirect comparison of pneumonia in randomized controlled trials
}

David Halpin, Joe Gray, Steven Edwards, Jeremy Morais, Dave Singh

\section{- To cite this version:}

David Halpin, Joe Gray, Steven Edwards, Jeremy Morais, Dave Singh. Budesonide/formoterol versus salmeterol/fluticasone in COPD: a systematic review and adjusted indirect comparison of pneumonia in randomized controlled trials. International Journal of Clinical Practice, 2011, 65 (7), pp.764. 10.1111/j.1742-1241.2011.02685.x . hal-00652664

\section{HAL Id: hal-00652664 https://hal.science/hal-00652664}

Submitted on 16 Dec 2011

HAL is a multi-disciplinary open access archive for the deposit and dissemination of scientific research documents, whether they are published or not. The documents may come from teaching and research institutions in France or abroad, or from public or private research centers.
L'archive ouverte pluridisciplinaire HAL, est destinée au dépôt et à la diffusion de documents scientifiques de niveau recherche, publiés ou non, émanant des établissements d'enseignement et de recherche français ou étrangers, des laboratoires publics ou privés. 


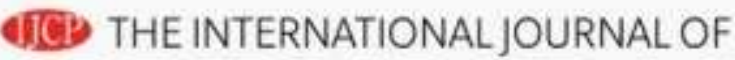 CLINICAL PRACTICE}

\section{Budesonide/formoterol versus salmeterol/fluticasone in COPD: a systematic review and adjusted indirect comparison of pneumonia in randomized controlled trials}

\begin{tabular}{|c|c|}
\hline Journal: & International Journal of Clinical Practice \\
\hline Manuscript ID: & IJCP-08-10-0441.R2 \\
\hline Wiley - Manuscript type: & Meta-Analysis \\
\hline $\begin{array}{r}\text { Date Submitted by the } \\
\text { Author: }\end{array}$ & 23-Feb-2011 \\
\hline Complete List of Authors: & $\begin{array}{l}\text { Halpin, David; Royal Devon \& Exeter Hospital, Department of } \\
\text { Respiratory Medicine } \\
\text { Gray, Joe; AstraZeneca UK Ltd, Outcomes Research } \\
\text { Edwards, Steven; AstraZeneca UK Ltd, Outcomes Research } \\
\text { Morais, Jeremy; AstraZeneca UK Ltd, Medical } \\
\text { Singh, Dave; University Hospital of South Manchester NHS } \\
\text { Foundation Trust, Medicines Evaluation Unit }\end{array}$ \\
\hline Specialty area: & \\
\hline
\end{tabular}

\section{SCHOLARONE" Manuscripts}




\section{Budesonide/formoterol versus salmeterol/fluticasone in COPD: a systematic review and adjusted indirect comparison of pneumonia in randomized controlled trials}

David MG Halpin, ${ }^{1}$ Joe Gray, ${ }^{2, *}$ Steven J Edwards, ${ }^{2}$ Jeremy Morais, ${ }^{3}$ and Dave Singh ${ }^{4}$

${ }^{1}$ Department of Respiratory Medicine, Royal Devon \& Exeter Hospital, Barrack Road, Exeter, EX2 5DW, United Kingdom.

${ }^{2}$ Outcomes Research, AstraZeneca UK Ltd, Horizon Place, 600 Capability Green, Luton, LU1 3LU, United Kingdom.

${ }^{3}$ Medical Department, AstraZeneca UK Ltd, Horizon Place, 600 Capability Green, Luton, LU1 3LU, United Kingdom.

${ }^{4}$ University of Manchester, Medicines Evaluation Unit, University Hospital of South Manchester NHS Foundation Trust, Southmoor Road, Manchester, M23 9QZ.

\section{Corresponding author}

Joe Gray, AstraZeneca UK Ltd, Horizon Place, 600 Capability Green, Luton, LU1 3LU, United Kingdom. Phone +44 1582836 614. Fax +44 161721 6405. Email joe.gray@ astrazeneca.com.

\section{Disclosures}

JG, SJE, and JM are full-time employees of AstraZeneca UK Ltd (correct at the time of final approval), the manufacturer of Symbicort ${ }^{\circledR}$. DMGH received funding from AstraZeneca for his involvement in this analysis and, beyond this project, has received sponsorship to attend international meetings and honoraria for lecturing, attending advisory boards, and preparing educational materials from AstraZeneca, Boehringer Ingelheim, Chiesi, GlaxoSmithKline (the manufacturer of Seretide ${ }^{\circledR}$ ), Nycomed, and Pfizer. His department has received research funding from AstraZeneca. DS received funding from AstraZeneca for his involvement in this analysis and, beyond this project, has received sponsorship to attend international meetings, honoraria for lecturing or attending advisory boards, and research grants from various pharmaceutical companies including Almirall, AstraZeneca, Boehringer Ingelheim, Chiesi, Cipla, Forest, GlaxoSmithKline, Novartis, Pfizer, and UCB. 


\section{Aim}

This analysis was designed to provide a comparison between budesonide/formoterol and salmeterol/fluticasone for the relative incidence of pneumonia adverse events, pneumonia serious adverse events, and pneumonia-related mortality, in patients being treated for chronic obstructive pulmonary disease.

\section{Methods}

An initial literature search revealed no suitable head-to-head trials between budesonide/formoterol and salmeterol/fluticasone and therefore a systematic review was conducted to find randomized controlled trials providing data for input into an adjusted indirect comparison of the two combination treatments, using placebo as a common comparator. The Bucher adjusted indirect comparison method was used to calculate odds ratios and $95 \%$ confidence intervals.

\section{Results}

Eight salmeterol/fluticasone trials and four budesonide/formoterol trials were identified as being relevant for the analyses. The proportion of patients experiencing a pneumonia adverse event was significantly lower with budesonide/formoterol than salmeterol/fluticasone (odds ratio, 0.47; 95\% confidence interval, $0.28-0.80$ ). The proportion of patients experiencing a pneumonia serious adverse event was also significantly lower with budesonide/formoterol than salmeterol/fluticasone (odds ratio, $0.41 ; 95 \%$ confidence interval, 0.19-0.86). However, there were too few events to draw any firm conclusions on pneumonia-related mortality.

\section{Conclusion}

The results of the indirect comparison support the hypothesis that budesonide/formoterol is associated with fewer pneumonia events than salmeterol/fluticasone in chronic obstructive pulmonary disease. The limitations of the analysis are that the results from a single study, TORCH, have a large bearing on the overall findings of the analysis, and that there is heterogeneity in the length and the dosing of the included studies, although it does not appear that heterogeneity affected the reported results. Another important limitation is the lack of pre-defined diagnostic standards for pneumonia in these studies.

\section{What's known}

When analysed at a class level, inhaled corticosteroid therapy in patients with chronic obstructive pulmonary disease (COPD) has been linked to an increased risk of pneumonia but not an increased risk of all-cause mortality or pneumonia-related mortality. However, a recent publication suggested that inhaled budesonide-containing therapy was not linked to an increased risk of pneumonia adverse events.

\section{What's new}

While no head-to-head randomized controlled trials shed light on whether a difference in pneumonia risk exists between budesonide/formoterol and salmeterol/fluticasone, the Bucher adjusted indirect comparison method enables placebo to be used as a common comparator in addressing the question. 
The results of the indirect comparison support the hypothesis that budesonide/formoterol is associated with fewer pneumonia events than salmeterol/fluticasone in COPD. 


\section{Introduction}

Inhaled corticosteroid (ICS) treatment is commonly used in chronic obstructive pulmonary disease (COPD), particularly as add-on therapy to long-acting bronchodilators (1). The addition of ICS treatment has been shown to improve exacerbation outcomes and quality of life in patients with a forced expiratory volume in 1 second $\left(\mathrm{FEV}_{1}\right)$ value $<50 \%$ predicted and a history of repeated exacerbations (2-5). ICS treatments are usually combined with a long-acting beta-2 agonist (LABA) in a combination inhaler for convenience of administration. However, the TORCH study results showed a statistically significant increase in the probability of the occurrence of non-fatal pneumonia when patients were treated with a study medication containing fluticasone propionate, relative to other treatments (4). This observation was also seen in the INSPIRE study, in which the combination inhaler salmeterol/fluticasone was compared with the inhaled long-acting anticholinergic bronchodilator tiotropium (5).

Subsequently, several groups have performed systematic reviews comparing pneumonia rates in patients being treated for COPD, the results of which can be used to explore whether the increased pneumonia rates reported are a class effect (6-9). When analysed at a class level, ICS therapy in patients with COPD has been linked to an increased risk of pneumonia but not an increased risk of allcause mortality or pneumonia-related mortality $(6,8,9)$. However, a recent publication by Sin and colleagues suggested that inhaled budesonide-containing therapy was not linked to an increased risk of pneumonia adverse events (AEs) (7).

These findings seem to indicate that different ICS therapies have different pharmacological effects, with resulting differences in the rates of pneumonia AEs and serious adverse events (SAEs), but more work is required to better elucidate the relationships. The previous systematic reviews included data from patients with COPD who were treated with an ICS alone or in combination with a LABA. In clinical practice, ICS treatments are usually combined with a LABA in a single inhaler; therefore, the present analysis focused on pneumonia with such combination treatments. Specifically, a systematic review was conducted to compare the two most commonly used LABA/ICS combination treatments: budesonide/formoterol (Symbicort ${ }^{\circledR}$; AstraZeneca, Luton, UK) and salmeterol/fluticasone (Seretide ${ }^{\circ}$; GlaxoSmithKline, Uxbridge, UK).

The present analysis was designed to address the question: "In patients with COPD, how does treatment with budesonide/formoterol compare against treatment with salmeterol/fluticasone in terms of the relative incidences of pneumonia AEs, pneumonia SAEs, and pneumonia-related mortality?"

\section{Methods}

A systematic review of the literature was conducted to identify randomized controlled trials with a head-to-head comparison of budesonide/formoterol and salmeterol/fluticasone that would facilitate a standard pair-wise meta-analysis. The necessary dataset was found to be absent from the literature; therefore, in line with the research protocol, a further systematic literature search was conducted to find randomized controlled trials that would enable an adjusted indirect comparison of budesonide/formoterol and salmeterol/fluticasone, using placebo as a common comparator between the trials. 


\section{Literature search}

The following bibliographic databases were searched for papers and abstracts:

- the Cochrane Central Register of Controlled Trials (CENTRAL);

- the Excerpta Medica Database (EMBASE);

- the Index Medicus database (MEDLINE).

The search strategies were tailored to comply with the precise functionality of each database, but all included terms for COPD and the treatments of interest. In order to limit the search results to randomized controlled trials (studies with a design that minimizes bias), a strategy based on the highly sensitive method from the Cochrane Handbook for Systematic Reviews of Interventions was used to identify relevant trials in MEDLINE (Table 1 provides the full strategy used for searching MEDLINE, as an example) (10). A similar approach was used for EMBASE. The systematic review was limited to English-language publications. The literature search was conducted in August 2009.

Trial databases of the manufactures of the treatments being considered (AstraZeneca and GlaxoSmithKline) were also searched, as was ClinicalTrials.gov (11-13). Furthermore, relevant systematic reviews identified as part of the literature search were checked for randomized controlled trials that had been missed. Finally, because the CENTRAL database includes the results of hand searches relevant to the subject area, further hand searching was not conducted as it was considered unlikely to be of benefit.

\section{Inclusion criteria}

To be eligible for inclusion in the systematic review, a trial needed to:

- be randomized and controlled;

- include a comparison of budesonide/formoterol with placebo or salmeterol/fluticasone with placebo;

- involve patients being treated for COPD;

- report at least one case of an outcome of interest.

\section{Assessment of data quality}

A clinical trial was considered appropriate for inclusion unless it demonstrated some feature that necessitated its exclusion. Two reviewers (JG and SJE) independently assessed the trials for inclusion, based on the rigorousness of techniques to minimize the risk of bias with regard to pneumonia outcomes. Assessment of data quality was conducted at a trial level rather than an outcome level, because the outcomes of interest were closely related and thus the risk of bias could be generalized across them.

\section{Data extraction}

Data extraction was carried out by JG using a pre-prepared form and then validated in full by SJE. Data were extracted where available on the following outcomes:

- pneumonia as an AE;

- pneumonia as a non-fatal SAE;

- pneumonia-related mortality.

If data were not available in the primary publication, trial reports on internal or external clinical study databases were used $(11,12)$. Only those AEs and SAEs with onset during randomized treatment were counted, if they were provided separately from all events. Similarly, only those deaths with the SAE 
onset during randomized treatment were counted if they were provided separately from all events. If pneumonia was presented as both an isolated preferred term and an aggregate of pneumonia-related preferred terms, then the latter was used. However, crude aggregates of pneumonia-related preferred terms were not made, owing to the associated risk of double-counting. In the event that there were two active comparator arms of interest with different dosages, the one offering greatest homogeneity with other trials and the most clinically relevant comparison was selected.

Data were recalculated in an intention-to-treat format, where they had not already been presented as such and it was possible to do so. Patients were reinstated into the analysis based on a worst-case assumption if they received at least one dose of study medication.

\section{Data analysis}

Adjusted indirect comparisons were performed in order to yield estimates of the relative differences in incidence of pneumonia AEs, pneumonia SAEs, and pneumonia-related mortality between budesonide/formoterol and salmeterol/fluticasone, using placebo as a data bridge. To conduct the adjusted indirect comparison for each of the three outcomes of interest, a traditional pair-wise MantelHaenszel random-effects meta-analysis was performed for budesonide/formoterol versus placebo and a second such meta-analysis was carried out for salmeterol/fluticasone versus placebo. The software used for this was Comprehensive Meta Analysis Version 2 (Biostat Inc, Englewood, NJ, USA). The Bucher method was employed to convert the summary estimates (log odds ratios) and measures of uncertainty (variances) from the two meta-analyses into an odds ratio and confidence interval representing the difference between budesonide/formoterol and salmeterol/fluticasone (14). The Bucher method is a commonly used and well-validated technique for performing adjusted indirect comparisons using a third therapy as a common comparator $(15,16)$.

\section{Assessment of heterogeneity and small-study effects}

The $I^{2}$ statistic was used to assess heterogeneity within each pair-wise comparison, following the guidance of Higgins and colleagues (17): “A naive categorisation of values for $I^{2}$ would not be appropriate for all circumstances, although we would tentatively assign adjectives of low, moderate, and high to $I^{2}$ values of $25 \%, 50 \%$, and $75 \%$." In order to check for the existence of small-study effects, it was planned to generate funnel plots for every outcome for which sufficient data were available to make them meaningful (defined by a minimum of 10 data points).

\section{Sensitivity analyses and subgroup analyses}

It has become relatively common practice for a fixed-effects model to be run as a sensitivity analysis if a random-effects model is used for the primary analysis, or for a sensitivity analysis to be conducted using the latter if the former has served as the primary analysis. However, the Bucher method has been validated for the random-effects model only (15), and so it was not appropriate to conduct a sensitivity analysis of this nature. (Song and colleagues opted for the random-effects model in their validation work because simulation studies suggested that indirect comparison using a fixed-effects model tended to underestimate standard errors of pooled estimates (15).) Therefore, sensitivity analysis was reserved for testing the dependence of the conclusions drawn to any assumptions introduced in handling the data. There were no pre-specified subgroup analyses. 
Using the search strategy, 1696 potentially relevant abstracts were retrieved. A flowchart of trials in the searching stage of the systematic review is shown in Figure 1. Twelve trials were identified as being relevant to the analysis: eight with a comparison of salmeterol/fluticasone versus placebo and four with a comparison of budesonide/formoterol versus placebo (see Table 2 for the characteristics of the 12 trials). All trials were double-blind, and none were excluded based on the assessment of risk of bias. A large majority of the events across the analyses came from the TORCH study (4). All trials involving budesonide/formoterol used the same dose of medication: $320 / 9 \mu \mathrm{g}$ bid. Seven of the salmeterol/fluticasone trials used a dose of 50/500 $\mu \mathrm{g}$ bid, but one used a dose of 50/250 $\mu \mathrm{g}$ bid (21).

Data from the 12 trials were used to run six pair-wise meta-analyses:

- pneumonia AEs for salmeterol/fluticasone versus placebo (Figure 2a) and for budesonide/formoterol versus placebo (Figure $2 b$ );

- pneumonia SAEs for salmeterol/fluticasone versus placebo (Figure 3a) and for budesonide/formoterol versus placebo (Figure $3 b$ );

- pneumonia-related mortality for salmeterol/fluticasone versus placebo (Figure 4a) and for budesonide/formoterol versus placebo (Figure $4 b$ ).

In three trials (18-20), only pneumonia SAEs and pneumonia-related mortality were provided in either the primary publication or the trial report on the clinical study registry. For these three studies, then, no $\mathrm{AE}$ data were available from primary sources. However, pneumonia AE data for these three trials were available in a systematic review conducted for the Cochrane Collaboration (27). In addition, pneumonia data for the TORCH study were taken from a secondary publication (28), because the results were not presented in the necessary format for this analysis in the primary publication (4). This was in line with the approach taken in another meta-analysis (8), where the data from the primary publication for TORCH were stated to be unsuitable.

\section{Assessment of heterogeneity and small-study effects}

The $I^{2}$ value was $0 \%$ for five of the six pair-wise meta-analyses, which was lower than the predefined threshold of at least $25 \%$ for low heterogeneity. The pair-wise meta-analysis comparing pneumonia AEs with budesonide/formoterol versus placebo was the exception, with an $I^{2}$ value of $23.3 \%$, but this was also less than the threshold indicating low heterogeneity. There were no more than eight trials available for any of the meta-analyses, which was two less than the pre-specified cut-off of 10 for generating funnel plots, and so no testing for small-study effects was possible.

\section{Adjusted indirect comparison results}

The results of the adjusted indirect comparison are shown in Table 3. The proportion of patients experiencing a pneumonia AE was significantly lower with budesonide/formoterol than with salmeterol/fluticasone (OR, 0.47; 95\% CI, 0.28-0.80). The proportion of patients experiencing a pneumonia SAE was also significantly lower with budesonide/formoterol than with salmeterol/fluticasone (OR, 0.41; 95\% CI, 0.19-0.86). However, there were too few events to draw any firm conclusions on pneumonia-related mortality.

\section{Sensitivity analyses}

Among the salmeterol/fluticasone trials, there was one in which the dosage was 50/250 $\mu \mathrm{g}$ bid (as compared with $50 / 500 \mu \mathrm{g}$ bid in the other seven) (21); therefore, we performed a sensitivity analysis in 
which this trial was excluded for pneumonia AEs and pneumonia SAEs (no pneumonia-related mortality was reported in the trial, and thus it did not contribute to the primary analysis for this outcome). In the sensitivity analysis, the results were either unchanged at the precision level of two decimal places (AEs: OR, 0.47 ; 95\% CI, 0.28-0.80) or changed only minimally (SAEs: OR, 0.40 ; $95 \%$ CI, 0.19-0.85).

\section{Discussion}

Therapy with inhalers containing combinations of ICS and LABA treatments has become a mainstay of COPD management. It is recommended by international guidelines and is associated with improved lung function, reductions in exacerbation rates, and improved health status (1-5). However, the TORCH study demonstrated a relationship between fluticasone use and pneumonia-related AEs (4). The recognition that the ICS component was associated with an increased incidence of pneumonia in the TORCH study was reported in the lay press and led to anxiety among patients about the safety of combination therapy. It was therefore important to determine if this effect was seen with all ICS/LABA combinations.

A meta-analysis of individual-patient-level data from seven trials of $\geq 6$ months' duration comparing inhaled budesonide-containing therapy with a control regimen in patients with COPD showed no significant difference between treatment groups for the occurrence of pneumonia either as an $\mathrm{AE}$ (adjusted hazard ratio [HR], 1.05; 95\% CI, 0.81-1.37) or as an SAE (adjusted HR, 0.92; 95\% CI, $0.62-$ 1.35) (7). A more recent, trial-level meta-analysis (9), which was a revised and updated version of a previous meta-analysis (8), reported a numerical increase in the risk of pneumonia with budesonide exposure, but this was not statistically significant (risk ratio [RR], 1.19; 95\% CI, 0.92-1.53). In contrast, the increased risk associated with fluticasone exposure was significant (RR, 1.67; 95\% CI, 1.47-1.89) (9). Statistically, however, it would not be appropriate to conclude from the significance of one finding and the non-significance of the other that there was an intraclass difference. The technique employed in the present analysis, in contrast, does offer a method of statistically comparing different therapy options. The analysis presented in this paper supports a difference between ICS/LABA products, with higher pneumonia incidences being observed with salmeterol/fluticasone than with budesonide/formoterol.

In order to statistically analyse the differences between budesonide/formoterol and salmeterol/fluticasone in the absence of suitable head-to-head data, it became necessary to perform an adjusted indirect comparison using the Bucher method, in line with the prespecified methods. For the approach to have clinical as well as statistical validity it was important that the placebo arms of the identified trials represented similar levels of care and, in particular, did not correspond to widely different concomitant medication across the trials. We do not believe that clinical differences in the therapy received by patients in the placebo arms of the trials were of sufficient magnitude to invalidate the statistical combination of the data they yielded. While there were some differences between trials, the arms for control and for the treatment of interest received the same medication, and the analysis explored a measure of relative risk rather than absolute risk, providing it with reasonable stability across different background risks.

The mean age of included patients and the mean $\mathrm{FEV}_{1}$ value as a percentage of the predicted level were reasonably similar across the 12 trials in the present analysis; however, there were differences in the bronchodilator responsiveness of patients included in the trials. Four trials, all involving salmeterol/fluticasone $(4,19,23,24)$, specified that patients should have poor reversibility and defined 
this as an increase of $<10 \%$ or $0.2 \mathrm{~L}$ in the $\mathrm{FEV}_{1}$ to inhalation of salbutamol. There were also marked differences in the proportion of current smokers included in the trials, with a range between $22 \%$ and $61 \%$. However, there was good within-trial balance resulting from well-conducted randomization; again, therefore, the fact that the analysis used relative risk rather than absolute risk provided it with reasonable stability across different background risks.

Pneumonia is usually diagnosed on the basis of a clinical history and examination with typical chest radiographic appearances. Laboratory investigations and sputum cultures are also often used to confirm the diagnosis. The clinical trials included in this systematic review did not specify that chest radiography was required to confirm the diagnosis of pneumonia; however, over two-thirds of the patients reported as having pneumonia in the TORCH study were found to have definite or presumptive evidence of having had a chest radiograph (28). Nevertheless, the lack of a definitive diagnosis of pneumonia and a standardised definition is obviously a limitation of the current and all other analyses of ICS-associated pneumonia in patients with COPD. There is a large variation between the incidence of pneumonia reported in previous trials; for example, the rates of pneumonia are substantially higher in the TORCH study compared with other trials of salmeterol/fluticasone. Such variation may be reflective of the lack of predefined diagnostic standards required for pneumonia. Alternatively, there may be differences between the countries enrolling patients in the use of the term pneumonia.

Both budesonide/formoterol and salmeterol/fluticasone reduce the overall rate of exacerbations, and so at first glance any increase in the rate of pneumonia within this context is puzzling. In the TORCH study, there was no increase in pneumonia-related mortality with salmeterol/fluticasone (4), and thus it appears that the clinical course of any pneumonia is not changed by the use of this ICS. The mechanisms underlying the increased rates of pneumonia with salmeterol/fluticasone remain unclear, and may involve suppression of the innate immune system, which in turn reduces the body's ability to combat bacterial pathogens. Furthermore, it is not clear why there may be an increased risk of pneumonia with one therapy (salmeterol/fluticasone) but not with another (budesonide/formoterol). There may be subtle differences in the pharmacological properties of these inhaled therapies that alter the local immune responses in the lung in response to bacteria. For example, corticosteroids suppress alveolar macrophage function (29), and there may be differences between budesonide and fluticasone in their pharmacological actions on these cells. This may be particularly relevant for current cigarette smokers, as corticosteroids and cigarette smoke combine to amplify the suppression of macrophage innate immune function, which may leave the host more susceptible to bacterial pathogens (30). Another potential factor could be variation in the lipophilicity-hydrophilicity profile.

It is possible that the differences observed in the incidence of pneumonia between the therapies could have been an artefact that related to discrepancies in the duration of the trials. The effect was first seen in the 3-year TORCH study and it is possible that shorter trials may have missed the effect. However, the incidence of pneumonia appears fairly constant throughout the TORCH study, with lines on the Kaplan-Meier plots for time to first pneumonia diverging relatively uniformly over time, from before week 24 (28). Similarly, Kaplan-Meier plots for budesonide-containing therapy and control treatments over 12 months show a reasonably constant rate of pneumonia over time for both AEs and SAEs (7). We included all trials irrespective of their duration as we believed it was inappropriate to introduce an arbitrary cut-off; that stated, the shorter trials had relatively very little impact on the results of the comparison, since the low event counts they contributed gave them only a very small weighting in the analysis. 
Another point to consider is that in randomized controlled trials in COPD, it is well recognized that effective therapy leads to sicker patients remaining in the study for longer rather than dropping out (31). This could also have an effect on the incidence of pneumonia, since sicker patients may also be at greater risk of its development (28). However, this is unlikely to have resulted in the observed difference between the treatments as the drop-out rates were reasonably similar in the combination therapy groups across the trials (Table 2).

It is also possible that the differences observed in the incidence of pneumonia reflect the dose of ICS used rather than differences in the pharmacological properties of fluticasone and budesonide. All but one of the salmeterol/fluticasone trials used fluticasone $500 \mu \mathrm{g}$ bid, while all the budesonide/formoterol trials used budesonide $320 \mu \mathrm{g}$ bid. The one trial included in the analysis using fluticasone $250 \mu \mathrm{g}$ bid in the combination inhaler was an 8-week trial in which the incidence of pneumonia was $0 / 62$ in the salmeterol/fluticasone group and 1/64 in the placebo group (21). However, in two 52-week trials comparing salmeterol/fluticasone $50 / 250 \mu \mathrm{g}$ bid with salmeterol alone, the incidence of pneumonia was increased in patients receiving fluticasone $250 \mu \mathrm{g}$ bid in the combination inhaler (7\% versus $4 \%$ in one trial (32), and $7 \%$ versus $2 \%$ in the other (33)). Therefore, it seems unlikely that the differences observed in our analysis are due to differences in the dose of ICS.

We believe that this analysis provides important additional information about the pneumonia profile of commonly used therapies in COPD, but it also paves the way for additional research. We chose to perform an adjusted indirect comparison using placebo as a common comparator. While there are potential limitations of the Bucher method, they do not apply to the present analysis. Edwards and colleagues have highlighted that the technique "can only incorporate a single indirect comparator and cannot integrate any direct comparative data that may be available from randomised controlled trials of the comparison of interest" (16), but there were no head-to-head trials for us to be forced to exclude. It is also noted by Edwards and colleagues that: "Performing an indirect comparison using [the Bucher method] is relatively inefficient in mathematical terms. It has been estimated that four times the amount of data is required to provide the same precision around an indirect comparison as would be required for a direct comparison." However, the use of a single comparator yielded sufficient power to provide answers for both pneumonia AEs and pneumonia SAEs. Further analyses may be possible either using LABAs instead of placebo as the common comparator or opening up the analysis to more than one additional comparator, by using a mixed treatment comparison (also called a network meta-analysis) (16).

Both salmeterol/fluticasone and budesonide/formoterol reduce exacerbation rates, in addition to improving lung function and health status. The current evidence indicates that the therapeutic index of these therapies in the context of pneumonia rates in COPD is acceptable, as even in the case of salmeterol/fluticasone there is an overall reduction in exacerbations despite the increase in the risk of pneumonia. However, more attention could be paid to specific subgroups of patients who are at a greater risk of developing pneumonia. The TORCH study identified independent risk factors for the development of pneumonia while on fluticasone therapy, including a lower $\mathrm{FEV}_{1}$ value $(<50 \%$ predicted), a lower body mass index $\left(<25 \mathrm{~kg} / \mathrm{m}^{2}\right)$, age $>55$ years, and a history of previous exacerbations (28). $\mathrm{FEV}_{1}$ and age were also identified as risk factors in a meta-analysis of individualpatient-level for budesonide-containing therapy (7). Clearly, other factors may also influence prescribing decisions, including device preference for patients, cost, and pharmacological differences such as speed of onset of action. 
In the absence of suitable head-to-head data on pneumonia comparing salmeterol/fluticasone with budesonide/formoterol, the Bucher method was used to perform an adjusted indirect statistical comparison of the two combination products, using placebo as a common comparator. The proportion of patients experiencing a pneumonia $\mathrm{AE}$ was significantly lower with budesonide/formoterol than with salmeterol/fluticasone (OR, $0.47 ; 95 \% \mathrm{CI}, 0.28-0.80)$. The proportion of patients experiencing a pneumonia SAE was also significantly lower with budesonide/formoterol than with salmeterol/fluticasone (OR, $0.41 ; 95 \%$ CI, 0.19-0.86). However, there were too few events to draw any firm conclusions on pneumonia-related mortality. The limitations of the analysis are that the results from a single study, TORCH, have a large bearing on the overall findings of the analysis, and that there is heterogeneity in the length and the dosing of the included studies, although it does not appear that heterogeneity affected the reported results. Another important limitation is the lack of pre-defined diagnostic standards for pneumonia in these studies.

\section{Author Contributions}

DMGH made substantial contributions to data interpretation, drafting of the article, and critical revision of the article, and gave final approval of the article. JG made substantial contributions to research design, data collection and analysis, drafting of the article, and critical revision of the article, and gave final approval of the article. SJE made substantial contributions to research design, data collection and analysis, drafting of the article, and critical revision of the article, and gave final approval of the article. JM made substantial contributions to research design, data interpretation, drafting of the article, and critical revision of the article, and gave final approval of the article. DS made substantial contributions to data interpretation, drafting of the article, and critical revision of the article, and gave final approval of the article.

\section{Acknowledgements}

Source of funding: AstraZeneca UK Ltd. There are no individuals who contributed to the study or manuscript who do not qualify as authors. 
1. Global Initiative for Chronic Obstructive Lung Disease. Global Strategy for Diagnosis, Management, and Prevention of Chronic Obstructive Lung Disease. 2009; Available at: www.goldcopd.com/Guidelineitem.asp?11=2\&12=1\&intId=2003. Accessed March 2010.

2. Calverley PM, Boonsawat W, Cseke Z, Zhong N, Peterson S, Olsson H. Maintenance therapy with budesonide and formoterol in chronic obstructive pulmonary disease. Eur Respir J 2003; 22: 912-9.

3. Szafranski W, Cukier A, Ramirez A, et al. Efficacy and safety of budesonide/formoterol in the management of chronic obstructive pulmonary disease. Eur Respir J 2003; 21: 74-81.

4. Calverley PM, Anderson JA, Celli B, et al. Salmeterol and fluticasone propionate and survival in chronic obstructive pulmonary disease. $N$ Engl J Med 2007; 356: 775-89.

5. Wedzicha JA, Calverley PM, Seemungal TA, et al. The prevention of chronic obstructive pulmonary disease exacerbations by salmeterol/fluticasone propionate or tiotropium bromide. $\mathrm{Am}$ J Respir Crit Care Med 2008; 177: 19-26.

6. Drummond MB, Dasenbrook EC, Pitz MW, Murphy DJ, Fan E. Inhaled corticosteroids in patients with stable chronic obstructive pulmonary disease: A systematic review and metaanalysis. JAMA 2008; 300: 2407-16.

7. Sin DD, Tashkin D, Zhang X, et al. Budesonide and the risk of pneumonia: a meta-analysis of individual patient data. Lancet 2009; 374: 712-9.

8. Singh S, Amin AV, Loke YK. Long-term use of inhaled corticosteroids and the risk of pneumonia in chronic obstructive pulmonary disease. Arch Intern Med 2009; 169: 219-29.

9. Singh S, Loke YK. Risk of pneumonia associated with long-term use of inhaled corticosteroids in chronic obstructive pulmonary disease: a critical review and update. Curr Opin Pulm Med 2010; 16: $118-22$.

10. Higgins JP, Green S. Cochrane Handbook for Systematic Reviews of Interventions. 2009; Available at: www.cochrane-handbook.org. Accessed March 2010.

11. AstraZeneca. AstraZeneca Clinical Trials. Available at: www.astrazenecaclinicaltrials.com. Accessed March 2010.

12. GlaxoSmithKline. GSK Clinical Trial Register. Available at: www.gskclinicalstudyregister.com/. Accessed March 2010.

13. US National Institutes of Health. ClinicalTrials.gov. Available at: www.clinicaltrials.gov. Accessed March 2010.

14. Bucher HC, Guyatt GH, Griffith LE, Walter SD. The results of direct and indirect treatment comparisons in meta-analysis of randomized controlled trials. J Clin Epidemiol 1997; 50: 683-91.

15. Song F, Altman DG, Glenny AM, Deeks JJ. Validity of indirect comparison for estimating efficacy of competing interventions: empirical evidence from published meta-analyses. $B M J$ 2003; 326: 472-476.

16. Edwards SJ, Clarke MJ, Wordsworth S, Borrill J. Indirect comparisons of treatments based on systematic reviews of randomised controlled trials. Int J Clin Pract 2009; 63: 841-54.

17. Higgins JP, Thompson SG, Deeks JJ, Altman DG. Measuring inconsistency in meta-analyses. BMJ 2003; 327: 557-60.

18. Barnes NC, Qiu YS, Pavord ID, et al. Antiinflammatory effects of salmeterol/fluticasone propionate in chronic obstructive lung disease. Am J Respir Crit Care Med 2006; 173: 736-43.

19. Calverley P, Pauwels R, Vestbo J, et al. Combined salmeterol and fluticasone in the treatment of chronic obstructive pulmonary disease: a randomised controlled trial. Lancet 2003; 361: 449-56.

20. Mahler DA, Wire P, Horstman D, et al. Effectiveness of fluticasone propionate and salmeterol combination delivered via the Diskus device in the treatment of chronic obstructive pulmonary disease. Am J Respir Crit Care Med 2002; 166: 1084-91.

21. O'Donnell DE, Sciurba F, Celli B, et al. Effect of fluticasone propionate/salmeterol on lung hyperinflation and exercise endurance in COPD. Chest 2006; 130: 647-56.

22. GlaxoSmithKline. Result summary for SCO104925. 2008; Available at: www.gskclinicalstudyregister.com/files/pdf/21078.pdf. Accessed March 2010.

23. GlaxoSmithKline. Result summary for SCO30002. 2005; Available at: www.gskclinicalstudyregister.com/files/pdf/23674.pdf. Accessed March 2010.

24. Zheng J-, Yang L, Wu YM, et al. The efficacy and safety of combination salmeterol (50 mug)/fluticasone propionate (500 mug) inhalation twice daily via accuhaler in Chinese patients with COPD. Chest 2007; 132: 1756-63. 
25. Rennard SI, Tashkin DP, McElhattan J, et al. Efficacy and tolerability of budesonide formoterol in one hydrofluoroalkane pressurized metered-dose inhaler in patients with chronic obstructive pulmonary disease: Results from a 1-year randomized controlled clinical trial. Drugs 2009; 69: $549-65$.

26. Tashkin DP, Rennard SI, Martin P, et al. Efficacy and safety of budesonide and formoterol in one pressurized metered-dose inhaler in patients with moderate to very severe chronic obstructive pulmonary disease: results of a 6-month randomized clinical trial. Drugs 2008; 68: 1975-2000.

27. Nannini L, Cates CJ, Lasserson TJ, Poole P. Combined corticosteroid and long-acting betaagonist in one inhaler versus placebo for chronic obstructive pulmonary disease. Cochrane Database Syst Rev 2007; 4: CD003794.

28. Crim C, Calverley PM, Anderson JA, et al. Pneumonia risk in COPD patients receiving inhaled corticosteroids alone or in combination: TORCH study results. Eur Respir J 2009; 34: 641-7.

29. Armstrong J, Sargent C, Singh D. Glucocorticoid sensitivity of lipopolysaccharide-stimulated chronic obstructive pulmonary disease alveolar macrophages. Clin Exp Immunol 2009; 158: 74 83.

30. Kent LM, Fox SM, Farrow SN, Singh D. The effects of dexamethasone on cigarette smoke induced gene expression changes in COPD macrophages. Int Immunopharmacol 2010; 10: 57-64.

31. Keene ON, Vestbo J, Anderson JA, et al. Methods for therapeutic trials in COPD: lessons from the TORCH trial. Eur Respir J 2009; 34: 1018-23.

32. Ferguson GT, Anzueto A, Fei R, Emmett A, Knobil K, Kalberg C. Effect of fluticasone propionate/salmeterol (250/50 microg) or salmeterol (50 microg) on COPD exacerbations. Respir Med 2008; 102: 1099-108.

33. Anzueto A, Ferguson GT, Feldman G, et al. Effect of fluticasone propionate/salmeterol (250/50) on COPD exacerbations and impact on patient outcomes. COPD 2009; 6: 320-9. 


\section{Figures and tables}

Figure 1: Flowchart for trials in the systematic review.

Figure 2: Forest plot for pneumonia adverse events in the comparison of (a) salmeterol/fluticasone and placebo and (b) budesonide/formoterol and placebo.

Figure 3: Forest plot for pneumonia serious adverse events in the comparison of (a) salmeterol/fluticasone and placebo and (b) budesonide/formoterol and placebo.

Figure 4: Forest plot for pneumonia-related deaths in the comparison of (a) salmeterol/fluticasone and placebo and (b) budesonide/formoterol and placebo. 
Table 1: Search strategy for MEDLINE.

\begin{tabular}{|c|c|}
\hline \# & Search term \\
\hline 1 & RANDOMIZED CONTROLLED TRIAL.pt. \\
\hline 2 & CONTROLLED CLINICAL TRIAL.pt. \\
\hline 3 & RANDOMIZED CONTROLLED TRIAL.sh. \\
\hline 4 & RANDOM ALLOCATION.sh. \\
\hline 5 & DOUBLE BLIND METHOD.sh. \\
\hline 6 & SINGLE BLIND METHOD.sh. \\
\hline 7 & 1 or 2 or 3 or 4 or 5 or 6 \\
\hline 8 & (ANIMALS not HUMAN).sh. \\
\hline 9 & 20 \\
\hline 10 & CLINICAL TRIAL.pt. \\
\hline 11 & exp CLINICAL TRIALS/ \\
\hline 12 & (clin\$ adj25 trial\$).ti,ab. \\
\hline 13 & $((\operatorname{sing} 1 \$$ or doubl $\$$ or trebl\$ or tripl\$) adj25 (blind $\$$ or mask $\$)) . t i, a b$. \\
\hline 14 & random\$.ti,ab. \\
\hline 15 & 10 or 11 or 12 or 13 or 14 \\
\hline 16 & 15 not 8 \\
\hline 17 & 8 \\
\hline 18 & (4) \\
\hline 19 & exp Pulmonary Disease, Chronic Obstructive/ \\
\hline 20 & symbicort.mp. [mp=title, original title, abstract, name of substance word, subject heading word] \\
\hline 21 & seretide.mp. [mp=title, original title, abstract, name of substance word, subject heading word] \\
\hline 22 & advair.mp. [mp=title, original title, abstract, name of substance word, subject heading word] \\
\hline 23 & viani.mp. [mp=title, original title, abstract, name of substance word, subject heading word] \\
\hline 24 & fluticasone.mp. [mp=title, original title, abstract, name of substance word, subject heading word] \\
\hline 25 & budesonide.mp. [mp=title, original title, abstract, name of substance word, subject heading word] \\
\hline 26 & salmeterol.mp. [mp=title, original title, abstract, name of substance word, subject heading word] \\
\hline 27 & formoterol.mp. [mp=title, original title, abstract, name of substance word, subject heading word] \\
\hline 28 & eformoterol.mp. [mp=title, original title, abstract, name of substance word, subject heading word] \\
\hline 29 & 20 or 21 or 22 or 23 or 24 or 25 or 26 or 27 or 28 \\
\hline 30 & 18 and 19 and 29 \\
\hline
\end{tabular}


Table 2: Characteristics of included trials.

\begin{tabular}{|c|c|c|c|c|c|c|c|c|c|c|}
\hline Study name & $\begin{array}{c}\text { Active } \\
\text { comparator }\end{array}$ & $\begin{array}{l}\text { Total patients } \\
\text { randomized to } \\
\text { an arm of } \\
\text { interest }\end{array}$ & Length & $\begin{array}{c}\text { Study } \\
\text { locations }\end{array}$ & Concurrent medication & $\begin{array}{l}\text { Mean age } \\
\text { across the } \\
\text { combination } \\
\text { and placebo } \\
\text { groups (years) }\end{array}$ & $\begin{array}{l}\text { Current smokers } \\
\text { across the } \\
\text { combination and } \\
\text { placebo groups }\end{array}$ & $\begin{array}{l}\text { Mean baseline } \\
\text { FEV }_{1}(\% \\
\text { predicted })\end{array}$ & Reversibility & $\begin{array}{c}\text { Discontinuation } \\
\text { rates }\end{array}$ \\
\hline $\begin{array}{l}\text { Barnes } 2006 \\
\text { (18) }\end{array}$ & $\begin{array}{c}\text { Salm/flut } \\
50 / 500 \mu \mathrm{g} \text { bid }\end{array}$ & 141 & 13 weeks & $\begin{array}{l}18 \text { centres in } \\
\text { eight countries } \\
\text { from Europe }\end{array}$ & $\begin{array}{l}\text { During the study, the only concurrent } \\
\text { treatment permitted was ipratropium } \\
\text { bromide as required }\end{array}$ & 64 & $61 \%$ & $\begin{array}{l}58 \% \text { in the } \\
\text { combination } \\
\text { group and } 59 \% \\
\text { in the placebo } \\
\text { group }\end{array}$ & $\begin{array}{l}\text { Mean reversibility } \\
\text { of } 3.9 \% \text { in the } \\
\text { combination and } \\
\text { placebo groups }\end{array}$ & $\begin{array}{l}12 \% \text { in the } \\
\text { comparator group } \\
\text { and 5\% in the } \\
\text { placebo group }\end{array}$ \\
\hline $\begin{array}{l}\text { Calverley } \\
\text { 2003a (19) }\end{array}$ & $\begin{array}{c}\text { Salm/flut } \\
50 / 500 \mu \mathrm{g} \text { bid }\end{array}$ & 719 & 52 weeks & $\begin{array}{l}196 \text { centres in } \\
25 \text { countries } \\
\text { from Africa, } \\
\text { Europe, North } \\
\text { America, and } \\
\text { Oceania }\end{array}$ & $\begin{array}{l}\text { Inhaled salbutamol was used as relief } \\
\text { medication throughout the study, and } \\
\text { regular treatment with anticholinergics, } \\
\text { mucolytics, and theophylline was also } \\
\text { allowed }\end{array}$ & 63 & $50 \%$ & $\begin{array}{l}44.8 \% \text { in the } \\
\text { combination } \\
\text { group and } \\
44.2 \% \text { in the } \\
\text { placebo group }\end{array}$ & $\begin{array}{l}\text { Mean reversibility } \\
\text { of } 4.0 \% \text { in the } \\
\text { combination and } \\
\text { placebo groups }\end{array}$ & $\begin{array}{l}25 \% \text { in the } \\
\text { comparator group } \\
\text { and } 39 \% \text { in the } \\
\text { placebo group }\end{array}$ \\
\hline $\begin{array}{l}\text { Calverley } \\
2007 \text { (4) }\end{array}$ & $\begin{array}{c}\text { Salm/flut } \\
50 / 500 \mu \mathrm{g} \text { bid }\end{array}$ & 3091 & 156 weeks & $\begin{array}{l}466 \text { centres in } \\
42 \text { countries } \\
\text { from Africa, } \\
\text { Asia, Europe, } \\
\text { North America, } \\
\text { Oceania, and } \\
\text { South America }\end{array}$ & $\begin{array}{l}\text { Salbutamol was provided for use as relief } \\
\text { medication throughout the study, while } \\
\text { other permitted medications included } \\
\text { theophyllines, short-acting anticholinergic } \\
\text { agents, and short-acting beta- } 2 \text { agonists }\end{array}$ & 8 & $43 \%$ & $\begin{array}{l}44.3 \% \text { in the } \\
\text { combination } \\
\text { group and } \\
44.1 \% \text { in the } \\
\text { placebo group }\end{array}$ & $\begin{array}{l}\text { Mean reversibility } \\
\text { of } 3.6 \% \text { in the } \\
\text { combination group } \\
\text { and } 3.7 \% \text { in the } \\
\text { placebo group }\end{array}$ & $\begin{array}{l}34 \% \text { in the } \\
\text { comparator group } \\
\text { and } 44 \% \text { in the } \\
\text { placebo group }\end{array}$ \\
\hline $\begin{array}{l}\text { Mahler } 2002 \\
\quad(20)\end{array}$ & $\begin{array}{c}\text { Salm/flut } \\
50 / 500 \mu \mathrm{g} \text { bid }\end{array}$ & 346 & 24 weeks & $\begin{array}{l}69 \text { centres in } \\
\text { the United } \\
\text { States and its } \\
\text { territories }\end{array}$ & Patients were given salbutamol as needed & 63 & $50 \%$ & $\begin{array}{l}41 \% \text { in the } \\
\text { combination } \\
\text { and placebo } \\
\text { groups }\end{array}$ & $\begin{array}{l}\text { Reversibility to } \\
\text { salbutamol }(\geq 12 \% \\
\text { increase in } \mathrm{FEV}_{1} \\
\geq 0.2 \mathrm{~L}) \text { of } 51-56 \% \\
\text { across groups }\end{array}$ & $\begin{array}{l}32 \% \text { in the } \\
\text { comparator group } \\
\text { and } 38 \% \text { in the } \\
\text { placebo group }\end{array}$ \\
\hline $\begin{array}{l}\text { O'Donnell } \\
2006 \text { (21) }\end{array}$ & $\begin{array}{c}\text { Salm/flut } \\
50 / 250 \mu \mathrm{g} \text { bid }\end{array}$ & 126 & 8 weeks & $\begin{array}{l}22 \text { centres in } \\
\text { Canada and } \\
\text { United States }\end{array}$ & $\begin{array}{l}\text { Concurrent use of salbutamol, } \\
\text { ipratropium, and ipratropium/ } \\
\text { salbutamol combinations was permitted }\end{array}$ & 64 & $46 \%$ & $\begin{array}{c}39.5-42.5 \% \\
\text { across groups }\end{array}$ & $\begin{array}{l}\text { Response to } \\
\text { salbutamol of } 18.0 \% \\
\text { in the combination } \\
\text { group and } 13.9 \% \text { in } \\
\text { the placebo group }\end{array}$ & $\begin{array}{l}5 \% \text { in the } \\
\text { comparator group } \\
\text { and } 8 \% \text { in the } \\
\text { placebo group }\end{array}$ \\
\hline
\end{tabular}

International Journal of Clinical Practice 


\begin{tabular}{|c|c|c|c|c|c|c|c|c|c|c|}
\hline Study name & $\begin{array}{l}\text { Active } \\
\text { comparator }\end{array}$ & $\begin{array}{l}\text { Total patients } \\
\text { randomized to } \\
\text { an arm of } \\
\text { interest }\end{array}$ & Length & $\begin{array}{c}\text { Study } \\
\text { locations }\end{array}$ & Concurrent medication & $\begin{array}{l}\text { Mean age } \\
\text { across the } \\
\text { combination } \\
\text { and placebo } \\
\text { groups (years) }\end{array}$ & $\begin{array}{l}\text { Current smokers } \\
\text { across the } \\
\text { combination and } \\
\text { placebo groups }\end{array}$ & $\begin{array}{c}\text { Mean baseline } \\
\text { FEV }_{1}(\% \\
\text { predicted) }\end{array}$ & Reversibility & $\begin{array}{l}\text { Discontinuation } \\
\text { rates }\end{array}$ \\
\hline $\begin{array}{l}\mathrm{SCO} 104925 \\
(22)\end{array}$ & $\begin{array}{l}\text { Salm/flut } \\
50 / 500 \mu \mathrm{g} \text { bid }\end{array}$ & 81 & 12 weeks & $\begin{array}{l}11 \text { centres in } \\
\text { four countries } \\
\text { from Europe, } \\
\text { North America, } \\
\text { and South } \\
\text { America }\end{array}$ & NS & 64 & NS & NS & NS & $\begin{array}{l}10 \% \text { in the } \\
\text { comparator group } \\
\text { and } 10 \% \text { in the } \\
\text { placebo group }\end{array}$ \\
\hline $\begin{array}{l}\mathrm{SCO} 30002 \\
(23)\end{array}$ & $\begin{array}{l}\text { Salm/flut } \\
50 / 500 \mu \mathrm{g} \text { bid }\end{array}$ & 256 & 52 weeks & $\begin{array}{l}56 \text { centres in } \\
\text { Italy and } \\
\text { Poland }\end{array}$ & $\begin{array}{l}\text { Salbutamol was provided for use as relief } \\
\text { medication throughout the study }\end{array}$ & 65 & NS & NS & NS & $\begin{array}{l}34 \% \text { in the } \\
\text { comparator group } \\
\text { and } 32 \% \text { in the } \\
\text { placebo group }\end{array}$ \\
\hline $\begin{array}{l}\text { Zheng } 2007 \\
\quad(24)\end{array}$ & $\begin{array}{l}\text { Salm/flut } \\
50 / 500 \mu \mathrm{g} \text { bid }\end{array}$ & 445 & 24 weeks & $\begin{array}{l}12 \text { centres in } \\
\text { China }\end{array}$ & $\begin{array}{l}\text { Salbutamol was used as relief medication } \\
\text { and regular COPD treatment was } \\
\text { permitted throughout the study }\end{array}$ & 66 & $22 \%$ & $\begin{array}{l}47 \% \text { in the } \\
\text { combination } \\
\text { and placebo } \\
\text { groups }\end{array}$ & $\begin{array}{l}\text { Mean reversibility } \\
\text { of } 5.2 \% \text { in the } \\
\text { combination group } \\
\text { and } 5.0 \% \text { in the } \\
\text { placebo group }\end{array}$ & $\begin{array}{l}12 \% \text { in the } \\
\text { comparator group } \\
\text { and } 11 \% \text { in the } \\
\text { placebo group }\end{array}$ \\
\hline $\begin{array}{l}\text { Calverley } \\
2003 b(2)\end{array}$ & $\begin{array}{l}\text { Bud/form } \\
320 / 9 \mu \mathrm{g} \mathrm{bid}\end{array}$ & 510 & 52 weeks & $\begin{array}{l}109 \text { centres in } \\
15 \text { countries } \\
\text { from Africa, } \\
\text { Asia, Europe, } \\
\text { and South } \\
\text { America }\end{array}$ & $\begin{array}{l}\text { Terbutaline } 0.5 \mathrm{mg} \text { was permitted when } \\
\text { needed as reliever medication }\end{array}$ & 65 & $31 \%$ & $\begin{array}{l}36 \% \text { in the } \\
\text { combination } \\
\text { and placebo } \\
\text { groups }\end{array}$ & $\begin{array}{l}\text { Mean reversibility } \\
\text { of } 6 \% \text { in the } \\
\text { combination and } \\
\text { placebo groups }\end{array}$ & $\begin{array}{l}29 \% \text { in the } \\
\text { comparator group } \\
\text { and } 41 \% \text { in the } \\
\text { placebo group }\end{array}$ \\
\hline $\begin{array}{l}\text { Rennard } 2009 \\
(25)\end{array}$ & $\begin{array}{l}\text { Bud/form } \\
320 / 9 \mu \mathrm{g} \mathrm{bid}\end{array}$ & 975 & 52 weeks & $\begin{array}{l}237 \text { centres in } \\
\text { nine countries } \\
\text { from Europe } \\
\text { and North } \\
\text { America }\end{array}$ & $\begin{array}{l}\text { Permitted medication included: } \\
\text { ephedrine-free anti-tussives and } \\
\text { mucolytics; nasal corticosteroids; } \\
\text { ipratropium bromide (in patients who had } \\
\text { been receiving anticholinergic treatment } \\
\text { before the study); cardioselective beta- } \\
\text { adrenoceptor antagonists (in patients who } \\
\text { had been using beta-adrenoceptor } \\
\text { antagonists at a constant dose for } 6 \\
\text { months before screening without evidence } \\
\text { of bronchospasm); and study-provided } \\
\text { salbutamol as rescue medication. }\end{array}$ & 63 & $41 \%$ & $\begin{array}{l}38.6 \% \text { in the } \\
\text { combination } \\
\text { group and } \\
40.8 \% \text { in the } \\
\text { placebo group }\end{array}$ & $\begin{array}{l}\text { Reversibility }(\geq 12 \% \\
\text { increase in FEV } \\
\geq 0.2 \mathrm{~L}) \text { in } 30.4 \% \text { of } \\
\text { the combination } \\
\text { group and } 31.8 \% \text { of } \\
\text { the placebo group }\end{array}$ & $\begin{array}{l}27 \% \text { in the } \\
\text { comparator group } \\
\text { and } 36 \% \text { in the } \\
\text { placebo group }\end{array}$ \\
\hline
\end{tabular}




\begin{tabular}{|c|c|c|c|c|c|c|c|c|c|c|}
\hline Study name & $\begin{array}{l}\text { Active } \\
\text { comparator }\end{array}$ & $\begin{array}{l}\text { Total patients } \\
\text { randomized to } \\
\text { an arm of } \\
\text { interest }\end{array}$ & Length & $\begin{array}{c}\text { Study } \\
\text { locations }\end{array}$ & Concurrent medication & $\begin{array}{l}\text { Mean age } \\
\text { across the } \\
\text { combination } \\
\text { and placebo } \\
\text { groups (years) }\end{array}$ & $\begin{array}{l}\text { Current smokers } \\
\text { across the } \\
\text { combination and } \\
\text { placebo groups }\end{array}$ & $\begin{array}{c}\text { Mean baseline } \\
\text { FEV }_{1}(\% \\
\text { predicted })\end{array}$ & Reversibility & $\begin{array}{l}\text { Discontinuation } \\
\text { rates }\end{array}$ \\
\hline $\begin{array}{l}\text { Szafranski } \\
2003(3)\end{array}$ & $\begin{array}{l}\mathrm{Bud} / \text { form } \\
320 / 9 \mu \mathrm{g} \mathrm{bid}\end{array}$ & 413 & 52 weeks & $\begin{array}{l}89 \text { centres in } 11 \\
\text { countries from } \\
\text { Africa, Europe, } \\
\text { North America, } \\
\text { and South } \\
\text { America }\end{array}$ & $\begin{array}{l}\text { Terbutaline } 0.5 \mathrm{mg} \text { was permitted when } \\
\text { needed as reliever medication }\end{array}$ & 64 & $32 \%$ & $\begin{array}{l}36 \% \text { in the } \\
\text { combination } \\
\text { and placebo } \\
\text { groups }\end{array}$ & $\begin{array}{l}\text { Mean reversibility } \\
\text { of } 6 \% \text { in the } \\
\text { combination group } \\
\text { and } 5 \% \text { in the } \\
\text { placebo group }\end{array}$ & $\begin{array}{l}28 \% \text { in the } \\
\text { comparator group } \\
\text { and } 44 \% \text { in the } \\
\text { placebo group }\end{array}$ \\
\hline $\begin{array}{l}\text { Tashkin } 2008 \\
\quad(26)\end{array}$ & $\begin{array}{l}\text { Bud/form } \\
320 / 9 \mu \mathrm{g} \text { bid }\end{array}$ & 577 & 26 weeks & $\begin{array}{l}194 \text { centres in } \\
\text { five countries } \\
\text { from Africa, } \\
\text { Europe, and } \\
\text { North America }\end{array}$ & $\begin{array}{l}\text { Permitted medication included: } \\
\text { ephedrine-free anti-tussives and } \\
\text { mucolytics; nasal corticosteroids; } \\
\text { ipratropium bromide (if the patient had } \\
\text { been receiving anticholinergic treatment } \\
\text { before the study); cardioselective beta- } \\
\text { adrenoceptor antagonists (if the patient } \\
\text { had been using beta-adrenoceptor } \\
\text { antagonists at a constant dose for } 6 \\
\text { months before screening without evidence } \\
\text { of bronchospasm); and study-provided } \\
\text { salbutamol as rescue medication }\end{array}$ & 63 & $42 \%$ & $\begin{array}{l}39.1 \% \text { in the } \\
\text { combination } \\
\text { group and } \\
41.3 \% \text { in the } \\
\text { placebo group }\end{array}$ & $\begin{array}{l}\text { Reversibility }(\geq 12 \% \\
\text { increase in FEV } \\
\geq 0.2 \mathrm{~L}) \text { in } 37.2 \% \text { of } \\
\text { the combination } \\
\text { group and } 40.0 \% \text { of } \\
\text { the placebo group }\end{array}$ & $\begin{array}{l}14 \% \text { in the } \\
\text { comparator group } \\
\text { and } 26 \% \text { in the } \\
\text { placebo group }\end{array}$ \\
\hline
\end{tabular}

$\mathrm{COPD}=$ chronic obstructive pulmonary disease $; \mathrm{FEV}_{1}=$ forced expiratory volume in 1 second; $\mathrm{NS}=$ not supplied 
Table 3: Results of the indirect comparisons, using the Bucher method.

\begin{tabular}{|c|c|c|}
\hline Outcome & Odds ratio & 95\% confidence interval \\
\hline Pneumonia adverse events & 0.47 & $0.28-0.80$ \\
\hline Pneumonia serious adverse events & 0.41 & $0.19-0.86$ \\
\hline Pneumonia-related mortality & 0.18 & $0.01-4.10$ \\
\hline
\end{tabular}

Odds ratios $<1$ favour budesonide/formoterol. 


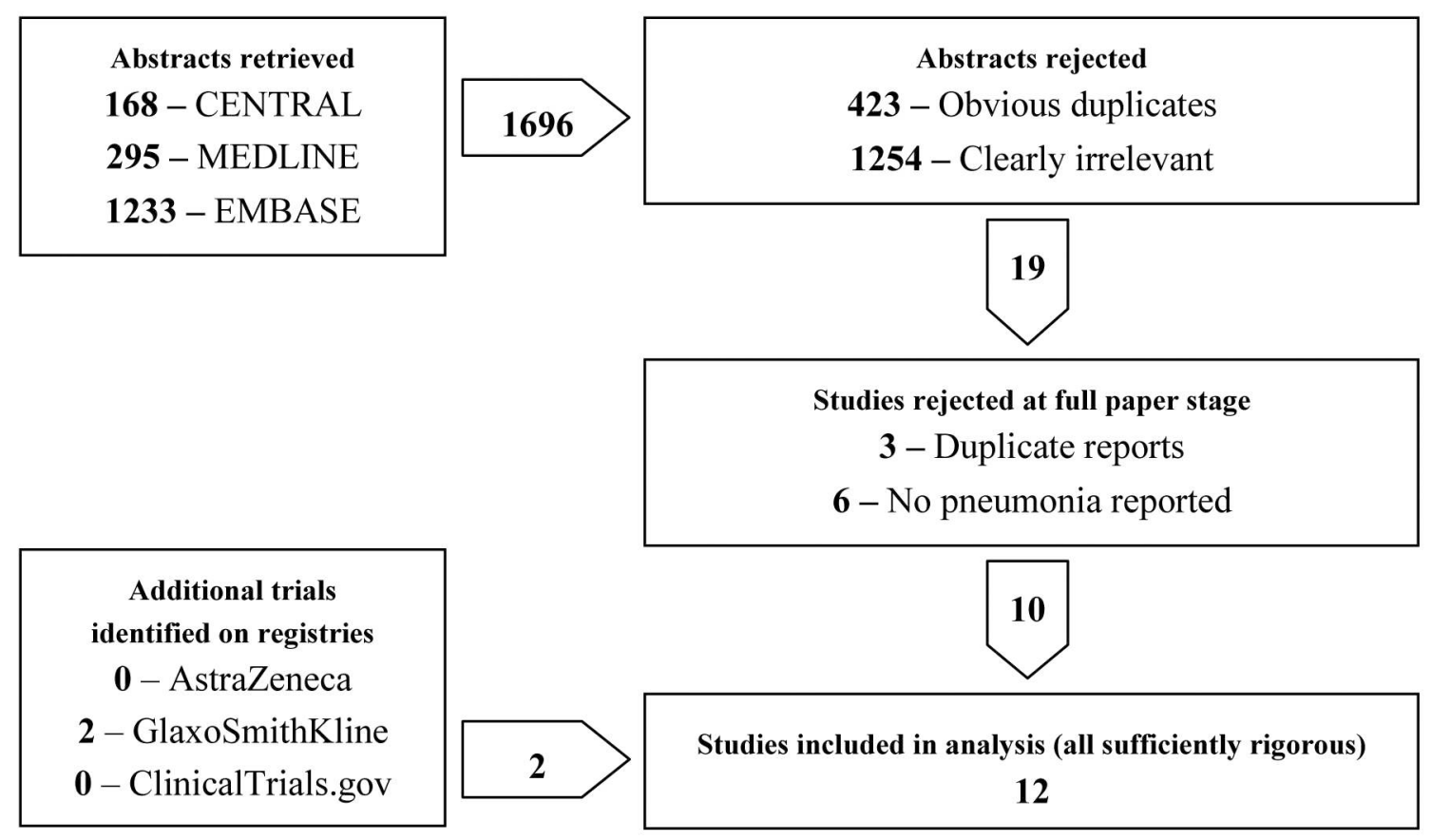


(a)

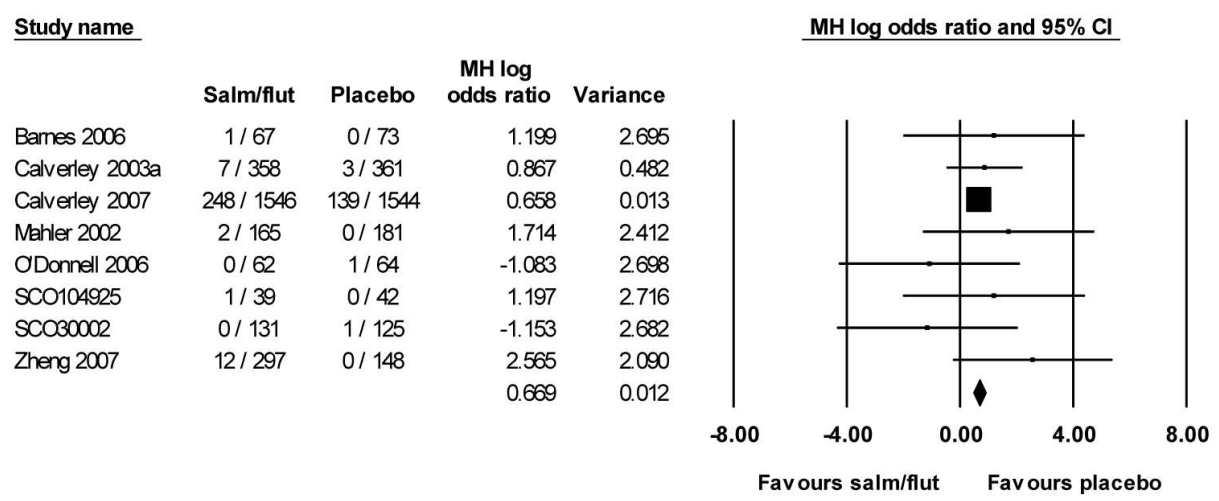

(b)

Study name

$$
\text { MH log }
$$

Bud/form Placebo odds ratio Variance

$\begin{array}{lccrl}\text { Calverley 2003b } & 7 / 254 & 2 / 256 & 1.281 & 0.651 \\ \text { Rennard 2009 } & 20 / 494 & 24 / 481 & -0.219 & 0.096 \\ \text { Szafransk 2003 } & 9 / 208 & 11 / 205 & -0.226 & 0.212 \\ \text { Tashkin 2008 } & 3 / 277 & 4 / 300 & -0.210 & 0.590 \\ & & & -0.082 & 0.061\end{array}$

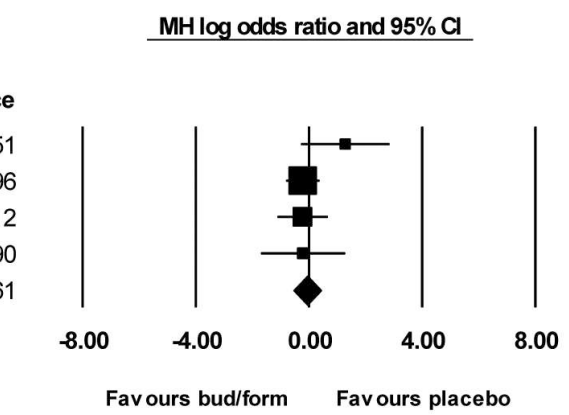

Bud/form = budesonide/formoterol; $\mathbf{C I}=$ confidence interval; MH $=$ Mantel-Haenszel; salm/flut $=$ salmeterol/fluticasone. For study name references see Table 2. 
(a)

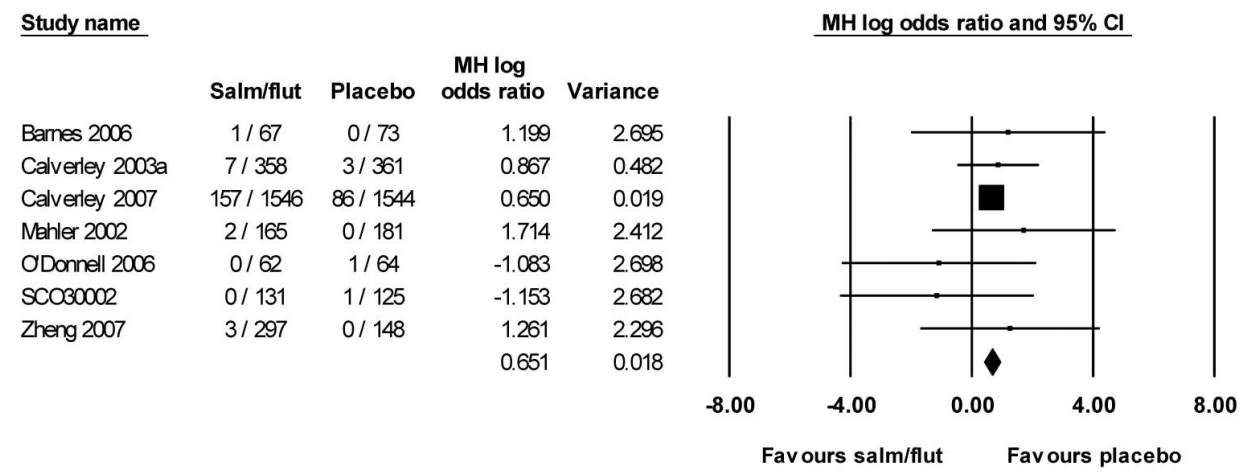

(b)

\begin{tabular}{|c|c|c|c|c|}
\hline \multicolumn{5}{|l|}{ Study name } \\
\hline & Bud/form & Placebo & $\begin{array}{l}\text { MH log } \\
\text { odds ratio }\end{array}$ & Variance \\
\hline Calverley $2003 b$ & $4 / 254$ & $1 / 256$ & 1.406 & 1.258 \\
\hline Rennard 2009 & $8 / 494$ & $12 / 481$ & -0.441 & 0.213 \\
\hline Szafranski 2003 & $3 / 208$ & $5 / 205$ & -0.536 & 0.543 \\
\hline Tashkin 2008 & $1 / 2 \pi 7$ & $1 / 300$ & 0.080 & 2007 \\
\hline & & & -0.243 & 0.1 \\
\hline
\end{tabular}

MH log odds ratio and $95 \% \mathrm{Cl}$ 
(a)

Study name

$\begin{array}{lccrrr} & \text { Bud/form } & \text { Placebo } & \begin{array}{r}\text { MH log } \\ \text { odds ratio }\end{array} & \text { Variance } \\ \text { Szafranski } 2003 & 0 / 208 & 2 / 205 & -1.634 & 2.410 \\ & & & -1.634 & 2.410\end{array}$

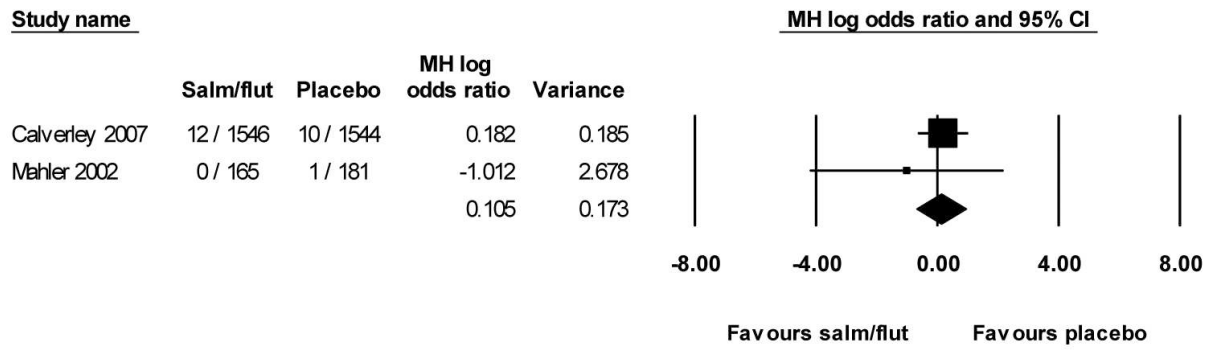

(b)

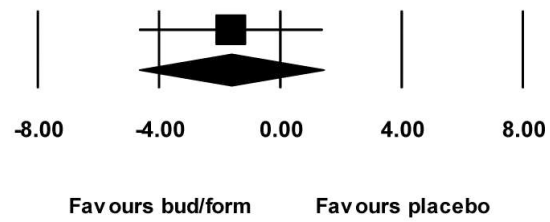

Bud/form = budesonide/formoterol; $\mathbf{C I}=$ confidence interval; $\mathbf{M H}=$ Mantel-Haenszel; salm/flut $=$ salmeterol/fluticasone. For study name references see Table 2 . 